\title{
Analysis of a Neutron Scattering Integral Experiment on Iron for Neutron Energies from 1 to $15 \mathrm{MeV}$
}

\author{
S. N. Cramer \\ E. M. Oblow
}

\section{OAK RIDGE NATIONAL LABORATORY}




\section{DISCLAIMER}

This report was prepared as an account of work sponsored by an agency of the United States Government. Neither the United States Government nor any agency Thereof, nor any of their employees, makes any warranty, express or implied, or assumes any legal liability or responsibility for the accuracy, completeness, or usefulness of any information, apparatus, product, or process disclosed, or represents that its use would not infringe privately owned rights. Reference herein to any specific commercial product, process, or service by trade name, trademark, manufacturer, or otherwise does not necessarily constitute or imply its endorsement, recommendation, or favoring by the United States Government or any agency thereof. The views and opinions of authors expressed herein do not necessarily state or reflect those of the United States Government or any agency thereof. 


\section{DISCLAIMER}

Portions of this document may be illegible in electronic image products. Images are produced from the best available original document. 


\section{Printed in the United States of America: Available from National Technical Information Service U.S. Department of Commerce 5285 Port Royal Road, Springfield, Virginia 22161 \\ Price: Printed Copy $\$ 4.00$; Microfiche $\$ 2.25$}

This report was prepared as an account of work sponsored by the United States Government. Neither the United States nor the Energy Research and Development Administration/United States Nuclear Regulatory Commission, nor any of their employees, nor any of their contractors, subcontractors, or their employees, makes any warranty, express or implied, or assumes any legal liability or responsibility for the accuracy, completeness or usefulness of any information, apparatus, product or process disclosed, or represents that its use would not infringe privately owned rights. 
ORNL/TM-5548

Contract No. W-7405-eng-26

Neutron Physics Division

ANALYSIS OF A NEUTRON SCATTERING INTEGRAL EXPERIMENT ON IRON FOR NEUTRON ENERGIES FROM 1 TO $15 \mathrm{MeV}$

S. N. Cramer and E. M. Oblow

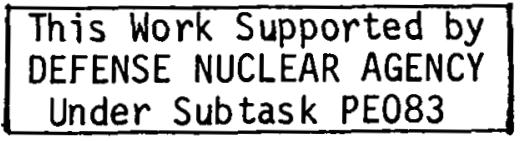

Date Published: November 1976

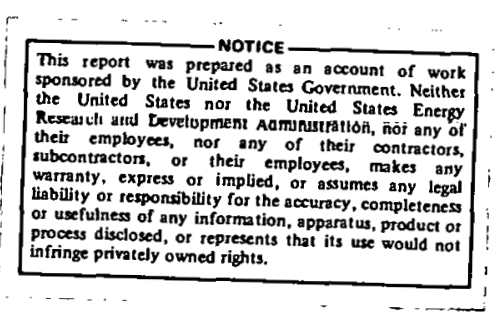

OAK RIDGE NATIONAL LABORATORY

Oak Ridge, Tennessee 37830 operated by

UNION CARB IDE CORPORATION for the

ENERGY RESEARCH AND DEVELOPMENT ADMINISTRATION 
ii,

Manuscript Typed by Virginia Glidewell

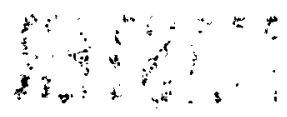




\section{Table of Contents}

Page No.

Abstract

I. Introduction

II. Experimental Arrangements

III. Calculated Model

A. Codes and Cross-Section Data

B. Calculation Procedure -...-...- 7

IV. Comparison of Experimental and Calculated Results --..-- 9

V. Discussion - 9

VI. Conclusions - 22 
THIS PAGE

\section{WAS INTENTIONALLY LEFT BLANK}




\section{Abstract}

Monte Carlo calculations were made to analyze the results of an integral experiment with an iron sample to determine the adequacy of neutron scattering cross-section data for iron. The experimental results analyzed included energy-dependent NE-213 detector count rates at a scattering angle of $90 \mathrm{deg}$ and pulse-height spectra for scattered neutrons produced in an iron ring pulsed with a 1- to 20-MeV neutron source. The pulse-height data were unfolded to generate secondary neutron spectra at $90 \mathrm{deg}$ as a function of incident neutron energy. Multigroup Monte Carlo calculations using the MORSE code and ENDF/B-IV cross sections were made to analyze all reported results. Discrepancies between calculated and measured responses were found for inelastic scattering reactions in the range from 1 to $4 \mathrm{MeV}$. These results were related to deficiencies in ENDF/B-IV iron cross-section data. 


\section{Acknowledgement}

The authors wish to acknowledge the aid of J. D. Drischler in preparing the graphical results. The multigroup cross sections were generated by W. E. Ford as part of the AMPX project of the Computer Sciences Division. 


\section{Introduction}

Calculations of neutron integral count rates and secondary neutron energy spectra were performed for comparison with the results of an integral measurement on iron. The calculations and the experiments ${ }^{1,2}$ were done at Oak Ridge National Laboratory as part of the Defense Nuclear Agency data testing program. This effort was designed to test neutron scattering and gamma-ray production data for several nuclides of interest to DNA for incident neutron energies from 1 to $15 \mathrm{MeV}$. The calculations, experiments, and comparisons presented here are similar to those already completed for carbon, ${ }^{3}$ nitrogen, ${ }^{4}$ and oxygen. ${ }^{5}$ The experimental procedures designed specifically for the data testing program are outlined in Ref. 2.

The current experiment consisted of a ring of natural iron pulsed by a collimated beam of neutrons traveling approximately 50 meters from source to sample. An NE-213 detector was used to detect the neutrons scattering from the sample. The data were reduced to neutron counts as a function of time and reported as counts per incident neutron as a function of incident neutron energy by using time-of-flight considerations. Pulse-height information was also recorded as a function of arrival time so that the differential spectrum of neutrons could be obtained by unfolding techniques as a function of incident neutron energy. The experimental data are reported in Ref. 1.

All calculations used to analyze the experiments were made with the MORSE ${ }^{6}$ multigroup Monte Carlo code using multigroup neutron cross-section data from the DNA library. ${ }^{7}$ processed by the AMPX ${ }^{8}$ code system. The results of the analysis are presented in the form of comparisons of the experimental and calculated results.

The experimental arrangement is described in Section II and the calculational model in Section III. Experimental and calculated results are presented in Section IV followed by a discussion in Section $V$ and conclusions in Section VI. 


\section{Experimental Arrangements}

The ORNL experimental setup is shown in Fig. 1. The Oak Ridge Electron Linear Accelerator (ORELA) was used to create a white pulsed neutron source (12 nsec burst width) from the $B e(\gamma, n)$ reaction. These neutrons were collimated into a beam which traveled along a 47.35-meter flight path to the scattering sample forming a uniformly distributed mono-directional source at the sample position. The source and flight path are shown in Fig. 2.

The scattering sample consisted of a stepped iron ring $25.38 \mathrm{~cm}$ in outer diameter, $15.30 \mathrm{~cm}$ in inner diameter, and $3.72 \mathrm{~cm}$ thick. The iron density was $7.826 \mathrm{gm} / \mathrm{cm}^{3}$ (complete specifications of the sample can be found in Ref. 1). A $4.22 \mathrm{~cm} \times 4.65 \mathrm{~cm} \mathrm{NE}-213$ detector was placed at the center of the ring creating a scattering angle of 90 deg with respect to the incident beam direction. The detector was shielded from the incident beam with a lead collimator. Experimental data was obtained in the form of integral count rates and pulse-height spectra as a function of incident neutron energy.

\section{Calculational Model}

A. Codes and Cross-Section Data

All calculations presented in this report were made with the MORSE ${ }^{6}$ multigroup Monte Carlo code using multigroup neutron cross-section data processed by the AMPX ${ }^{8}$ code system.

The iron cross-section data set used in the calculations was taken from the DNA MAT 4192 data file (equivalent to ENDF/B-IV MAT 1192). The sample was assumed to be pure iron with a density of 0.084402 atoms $/ \mathrm{barn}-\mathrm{cm}$.

The cross sections for this study were processed using AMPX into a 141 neutron group structure with a $P_{8}$ Legendre expansion. A $1 / E$ weighting function was used to simulate the incident source spectrum. The crosssection group structure is given in Table 1 along with the detector 


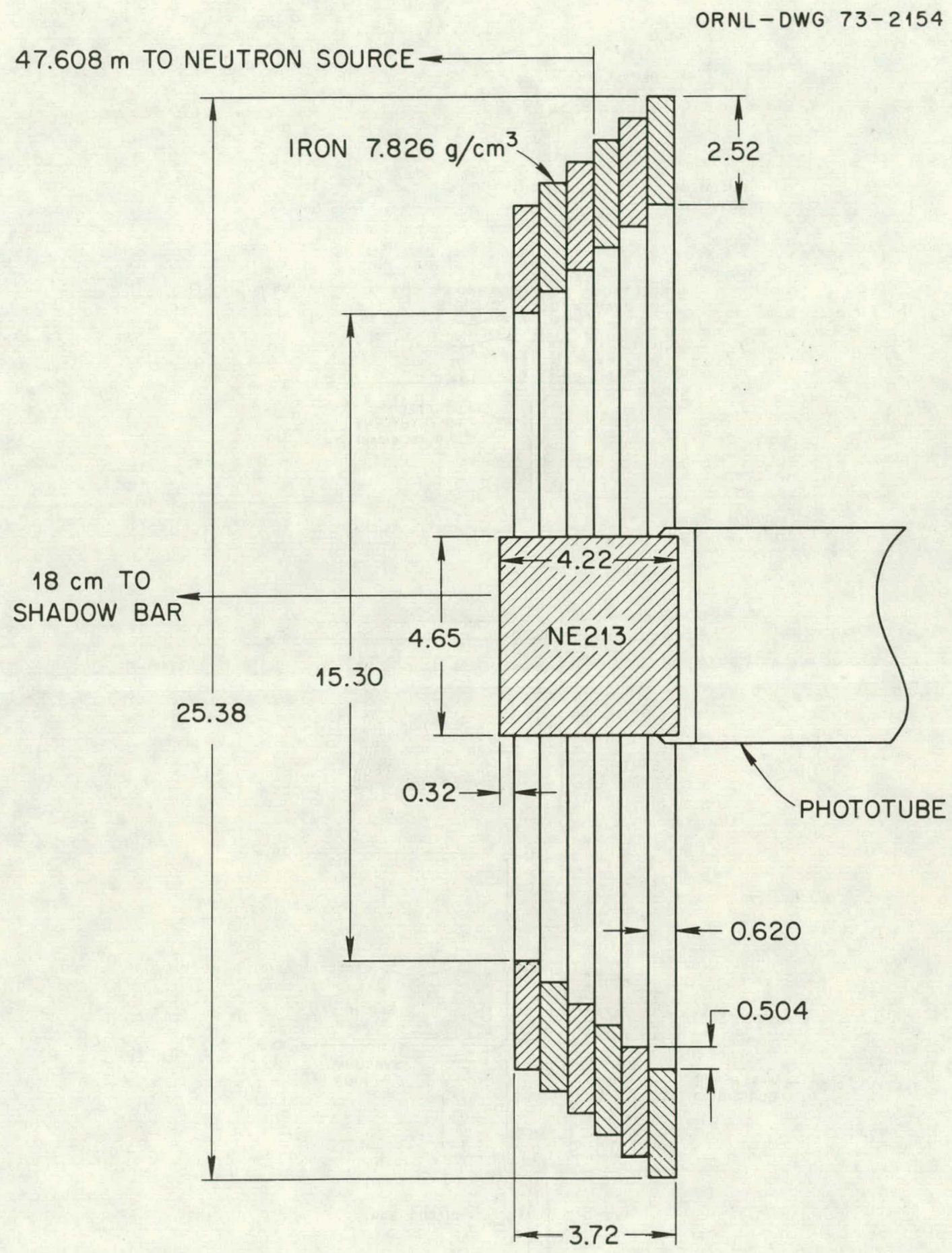

Fig. 1. Experimental Setup for the Iron Integral Experiment. 


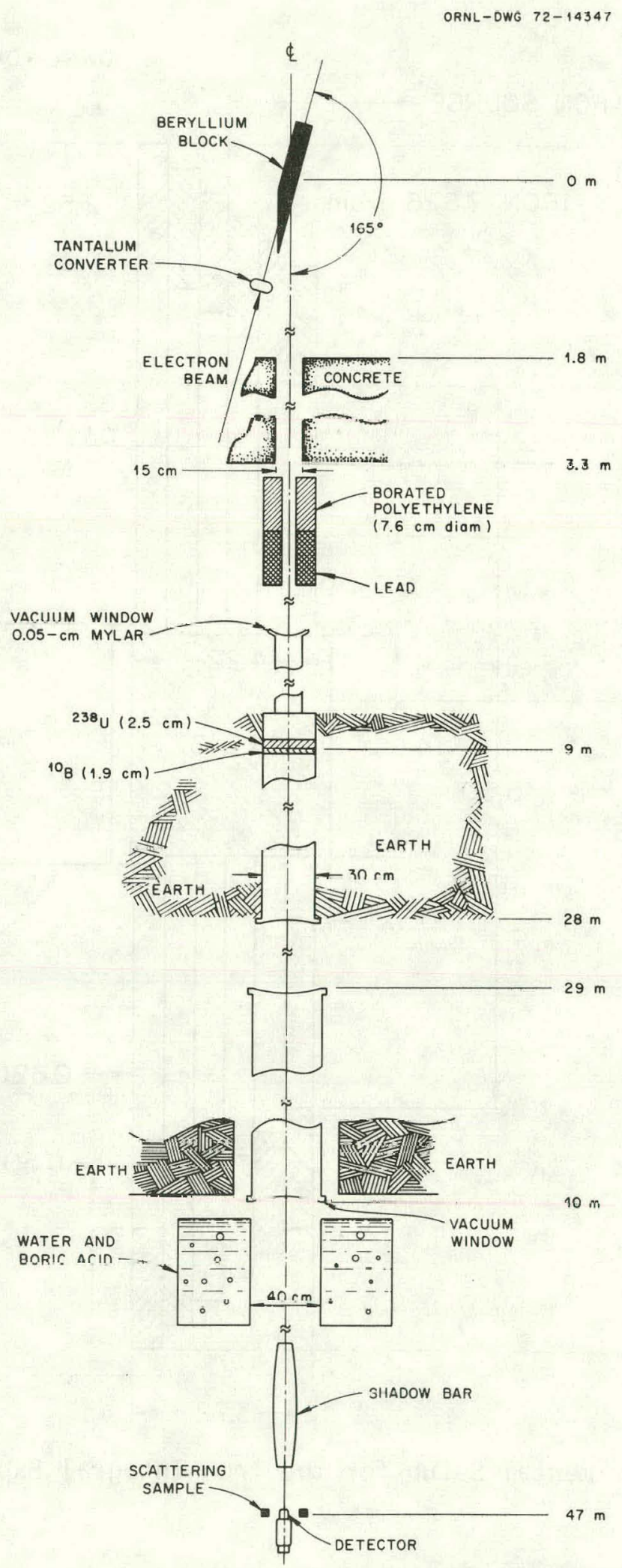

Fig. 2. Neutron Source and Flight Path at ORELA Used for ORNL Integra1 Experiment. 
Table I. Neutron Energy Group Structure and Detector Response

\begin{tabular}{|c|c|c|c|c|c|}
\hline $\begin{array}{c}\text { Group } \\
\text { No. }\end{array}$ & $\begin{array}{c}\text { Upper Energy } \\
(\mathrm{eV})\end{array}$ & $\begin{array}{l}\text { Detector } \\
\text { Response }\end{array}$ & $\begin{array}{c}\text { Group } \\
\text { No. }\end{array}$ & $\begin{array}{c}\text { Upper Energy } \\
(\mathrm{eV})\end{array}$ & $\begin{array}{l}\text { Detector } \\
\text { Response }\end{array}$ \\
\hline 1 & $2.0000 \mathrm{E} 07$ & $1: 5590 \mathrm{E}-01$ & 51 & $4.4631 \mathrm{E} 06$ & $2.6150 \mathrm{E}-01$ \\
\hline 2 & $1.9409 \mathrm{E} 07$ & $1.5600 \mathrm{E}-01$ & 52 & $4.3312 \mathrm{E} 06$ & $2.6490 \mathrm{E}-01$ \\
\hline 3 & $1.8835 \mathrm{E} 07$ & $1.5620 \mathrm{E}-01$ & 53 & $4.2022 \mathrm{E} 06$ & $2.6850 \mathrm{E}-01$ \\
\hline 4 & $1.8279 \mathrm{E} 07$ & $1.5650 E-01$ & 54 & $4.0790 \mathrm{E} 06$ & $2.7210 E-01$ \\
\hline 5 & $1.7739 \mathrm{E} 07$ & $1.5610 \mathrm{E}-01$ & 55 & $3.9584 \mathrm{E} 06$ & $2.7570 \mathrm{E}-01$ \\
\hline 6 & $1.7214 \mathrm{E} \quad 07$ & $1.5500 \mathrm{E}-01$ & 56 & $3.8414 \mathrm{E} 06$ & $2.7930 \mathrm{E}-01$ \\
\hline 7 & $1.6706 \mathrm{E} \quad 07$ & $1.5350 \mathrm{E}-01$ & 57 & $3.7279 \mathrm{E} 06$ & $2.8300 \mathrm{E}-01$ \\
\hline 8 & $1.6212 \mathrm{E} \quad 07$ & $1.5200 \mathrm{E}-01$ & 58 & $3.6177 \mathrm{E} 06$ & $2.8660 \mathrm{E}-01$ \\
\hline 9 & $1.5738 \mathrm{E} \quad 07$ & $1.5170 \mathrm{E}-01$ & 59 & $3.5108 \mathrm{E} 06$ & $2.9020 \mathrm{E}-01$ \\
\hline 10 & $1.5268 \mathrm{E} \quad 07$ & $1.5190 E-01$ & 60 & $3.4071 \mathrm{E} 06$ & $2.9380 E-01$ \\
\hline 11 & $1.4817 \mathrm{E} 07$ & $1.5240 \mathrm{E}-01$ & 61 & $3.3064 \mathrm{E} 06$ & $2.9740 \mathrm{E}-01$ \\
\hline 12 & $1.4379 \mathrm{E} 07$ & $.1 .5330 \mathrm{E}-01$ & 62 & $3.2087 \mathrm{E} 06$ & $3.0110 \mathrm{E}-01$ \\
\hline 13 & $1.3954 \mathrm{E} 07$ & $1.5450 \mathrm{E}-01$ & 63 & $3.1138 \mathrm{E} \quad 06$ & $3.0470 \mathrm{E}-01$ \\
\hline 14 & $1.3541 \mathrm{E} 07$ & $1.5610 \mathrm{E}-01$ & 64 & $3.0218 \mathrm{E} 06$ & $3.0830 E-01$ \\
\hline 15 & $1.3141 \mathrm{E} 07$ & $1.5800 \mathrm{E}-01$ & 65 & $2.9325 \mathrm{E} 06$ & $3.1190 \mathrm{E}-01$ \\
\hline 16 & $1.2758 \mathrm{E} 07$ & $1.6010 \mathrm{E}-01$ & 66 & $2.8459 \mathrm{E} 06$ & $3.1540 \mathrm{E}-01$ \\
\hline 17 & $1.2376 \mathrm{E} \quad 07$ & $1.6250 \mathrm{E}-01$ & 67 & $2.7610 \mathrm{E} \quad 06$ & $3.1890 \mathrm{E}-01$ \\
\hline 18 & $1.2010 \mathrm{E} 07$ & $1.6460 \mathrm{E}-01$ & 68 & $2.6801 \mathrm{E} \mathrm{OE}$ & $3.2240 E-01$ \\
\hline 19 & $1.1655 \mathrm{E} 07$ & $1.6610 \mathrm{E}-01$ & 69 & $2.6009 \mathrm{E} 06$ & $3.2580 \mathrm{E}-01$ \\
\hline 20 & $1.1311 E 07$ & $1.6740 \mathrm{E}-01$ & 70 & $2.5241 \mathrm{E} 06$ & $3.2920 E-01$ \\
\hline 21 & $1.0977 \mathrm{E} 07$ & $1.6870 \mathrm{E}-01$ & 71 & $2.4495 \mathrm{E} 06$ & $3.3260 \mathrm{E}-01$ \\
\hline 22 & $1.0652 \mathrm{E} 07$ & $1.6890 \mathrm{E}-01$ & 72 & $2.3771 \mathrm{E} 06$ & $3.3590 \mathrm{E}-01$ \\
\hline 23 & $1.0337 \mathrm{E} 07$ & $1.7080 \mathrm{E}-01$ & 73 & $2.3068 \mathrm{E} 06$ & $3.3920 \mathrm{E}-01$ \\
\hline 24 & $1.0032 \mathrm{E} 07$ & $1.7220 \mathrm{E}-01$ & 74 & $2.2387 \mathrm{E} 06$ & $3.4240 \mathrm{E}-01$ \\
\hline 25 & $9.7355 \mathrm{E} 06$ & $1.7420 \mathrm{E}-01$ & 75 & $2.1725 \mathrm{E} 06$ & $3.4550 E-01$ \\
\hline 26 & $9.4478 \mathrm{E} \quad 06$ & $1.7630 \mathrm{E}-01$ & 76 & $2.1083 \mathrm{E} 06$ & $3.4860 E-01$ \\
\hline 27 & $9.1686 \mathrm{E} 06$ & $1.7860 \mathrm{E}-01$ & 77 & $2.0460 \mathrm{E} 06$ & $3.5170 E-01$ \\
\hline 28 & $8.8976 E \quad 06$ & $1.8090 \mathrm{E}-0 \mathrm{I}$ & 78 & $1.9855 \mathrm{E} \quad 06$ & $3.5470 \mathrm{E}-01$ \\
\hline 29 & $8.6347 \mathrm{E} 06$ & $1.8340 \mathrm{E}-01$ & 79 & $1.9269 \mathrm{E} 06$ & $3.5760 \mathrm{E}-01$ \\
\hline 30 & $8.3795 E \quad 06$ & $1.8600 \mathrm{E}-01$ & 80 & $1.8699 \mathrm{E} 06$ & $3.6050 \mathrm{E}-01$ \\
\hline 31 & $8.1319 \mathrm{E} 06$ & $1.8870 \mathrm{E}-01$ & 81 & $1.8146 \mathrm{E} 06$ & $3.6340 E-01$ \\
\hline 32 & $7.89 .16 \mathrm{E} 06$ & $1.9160 \mathrm{E}-01$ & 82 & $1.7610 \mathrm{E} 06$ & $3.6610 \mathrm{E}-01$ \\
\hline 33 & $7.6584 E \quad 06$ & $1.9460 \mathrm{E}-01$ & 83 & $1.7090 \mathrm{E} 06$ & $3.6890 \mathrm{E}-01$ \\
\hline 34 & $7.4320 E$ O6 & $1.9780 \mathrm{E}-01$ & 84 & $1.6585 \mathrm{E} 06$ & $3.7150 \mathrm{E}-01$ \\
\hline 35 & $7.2124 \mathrm{E} \quad 06$ & $2.0100 E-01$ & 85 & $1.6095 \mathrm{E} 06$ & $3.7430 \mathrm{E}-01$ \\
\hline 36 & $6.9993 E 06$ & $2.0460 \mathrm{E}-01$ & 86 & $1.5619 \mathrm{E} 06$ & $3.7720 \mathrm{E}-01$ \\
\hline 37 & $6.7924 \mathrm{E} 06$ & $2.0860 \mathrm{E}-01$ & 87 & $1.5157 \mathrm{E} 06$ & $3.8010 E-01$ \\
\hline 38 & $6.5917 \mathrm{E} 06$ & $2.1290 \mathrm{E}-01$ & 88 & $1.4709 \mathrm{E} 06$ & $3.8290 E-01$ \\
\hline 39 & $6.3969 \mathrm{E} 06$ & $2.1730 \mathrm{E}-01$ & 89 & $1.4275 \mathrm{E} \quad 06$ & $3.8570 E-01$ \\
\hline 40 & $6.2078 \mathrm{E} \quad 06$ & $2.2190 \mathrm{E}-01$ & 90 & $1.3853 \mathrm{E} 06$ & $3.8850 E-01$ \\
\hline 41 & $6.0244 \mathrm{E} 06$ & $2.2620 \mathrm{E}-01$ & 91 & $1.3444 \mathrm{E} 06$ & $3.9130 \mathrm{E}-01$ \\
\hline 42 & $5.8463 E \quad 06$ & $2.3010 \mathrm{E}-01$ & 92 & $1.3046 \mathrm{E} 06$ & $3.9400 \mathrm{E}-01$ \\
\hline 43 & $5.6736 \mathrm{E} 06$ & $2.3380 \mathrm{E}-01$ & 93 & $1.2661 \mathrm{E} 06$ & $3.9670 \mathrm{E}-01$ \\
\hline 44 & $5.5059 \mathrm{E} \quad 06$ & $2.3740 \mathrm{E}-0 \mathrm{I}$ & 94 & $1.2287 \mathrm{E} 06$ & $3.9930 \mathrm{E}-01$ \\
\hline 45 & $5.3432 E \quad 06$ & $2.4090 \mathrm{E}-01$ & 95 & $1.1923 \mathrm{E} \quad 06$ & $4.0100 E-01$ \\
\hline 46 & $5.1858 \mathrm{E} 06$ & $2.4430 \mathrm{E}-01$ & 96 & $1.1571 \mathrm{E} 06$ & $4.0240 E-01$ \\
\hline 47 & $5.0320 \mathrm{E} \quad 06$ & $2.4760 \mathrm{E}-01$ & 9.7 & $1.1229 \mathrm{E} 06$ & $4.0360 \mathrm{E}-01$ \\
\hline 48 & $4.8833 \mathrm{E} 06$ & $2.5110 \mathrm{~F}-01$ & 98 & $1.0897 \mathrm{E} 06$ & $4.0470 \mathrm{r}-01$ \\
\hline 49 & $4.7390 \mathrm{E} 06$ & $2.5460 \mathrm{E}-01$ & 99 & $1.0575 \mathrm{E} 06$ & $4.0560 \mathrm{E}-01$ \\
\hline 50 & $4.5990 \mathrm{E} 06$ & $2.5800 \mathrm{E}-01$ & 100 & $1.0263 \mathrm{E} 06$ & $4.0640 \mathrm{E}-01$ \\
\hline
\end{tabular}


Table I (Cont'd.)

\begin{tabular}{|c|c|c|}
\hline $\begin{array}{l}\text { Group } \\
\text { No. }\end{array}$ & $\begin{array}{c}\text { Upper Energy } \\
(\mathrm{eV})\end{array}$ & $\begin{array}{l}\text { Detector } \\
\text { Response }\end{array}$ \\
\hline 101 & $9.9594 \mathrm{E} 05$ & $4.0700 \mathrm{E}-01$ \\
\hline 102 & $9.6650 \mathrm{E} 05$ & $4.0760 \mathrm{E}-01$ \\
\hline 103 & $9.3794 \mathrm{E} 05$ & $4.0810 \mathrm{E}-01$ \\
\hline 104 & $9.1022 \mathrm{E} 05$ & $4.0810 \mathrm{E}-01$ \\
\hline 105 & $8.8332 \mathrm{E} 05$ & $4.0740 \mathrm{E}-01$ \\
\hline 106 & $8.5722 \mathrm{E} \quad 05$ & $4.0640 \mathrm{E}-01$ \\
\hline 107 & 8. $3189 \mathrm{E}$ os & $4.0520 \mathrm{E}-01$ \\
\hline 108 & $8.0730 \mathrm{E} 05$ & $4.0390 \mathrm{E}-01$ \\
\hline 109 & $7.8345 \mathrm{E} 05$ & $4.0240 \mathrm{E}-01$ \\
\hline 110 & $7.6029 \mathrm{E} \quad 05$ & $4.008 \cap \mathrm{E}-01$ \\
\hline 111 & $7.3782 \mathrm{E} \quad 05$ & $3.9910 \mathrm{E}-01$ \\
\hline 112 & $7.1602 \mathrm{E} \quad 05$ & $3.9720 \mathrm{E}-01$ \\
\hline 113 & $6.9486 E \quad 05$ & $3.9530 \mathrm{E}-01$ \\
\hline 114 & $6.7432 \mathrm{E} \quad 05$ & $3.9330 \mathrm{E}-01$ \\
\hline $\begin{array}{l}214 \\
115\end{array}$ & $6.5440 \mathrm{E} 05$ & $3.9120 \mathrm{E}-01$ \\
\hline 116 & $6.3506 \mathrm{E} \quad 05$ & $3.8900 \mathrm{E}-01$ \\
\hline 117 & $6.1629 \mathrm{E} \quad 05$ & $3.8420 \mathrm{E}-01$ \\
\hline 118 & $5.9808 \mathrm{E} \quad 05$ & $3.7690 \mathrm{E}-01$ \\
\hline 119 & $5.8040 \mathrm{E} 05$ & $3.6910 \mathrm{E}-01$ \\
\hline 120 & $5.6325 \mathrm{E} 05$ & $3.6090 \mathrm{E}-01$ \\
\hline 121 & $5.4660 \mathrm{E} 05$ & $3.5250 \mathrm{E}-01$ \\
\hline 122 & $5.3045 \mathrm{E} \quad 05$ & $3.4370 \mathrm{E}-01$ \\
\hline 123 & $5.1478 E \quad 0.5$ & $3.3460 \mathrm{E}-01$ \\
\hline 124 & $4.9956 \mathrm{E} \quad 05$ & $3.2540 \mathrm{E}-01$ \\
\hline 125 & $4.8400 \mathrm{E} \quad 05$ & 3.16()$(1)-01$ \\
\hline 126 & $4.7047 \mathrm{E} 05$ & $3.0650 \mathrm{E}-\mathrm{UI}$ \\
\hline 127 & $4.5657 \mathrm{E} 05$ & $2.9680 \mathrm{E}-01$ \\
\hline 128 & $4.4308 \mathrm{E} 05$ & $2.8710 \mathrm{E}-01$ \\
\hline 129 & $4.2998 \mathrm{E} \quad 05$ & $2.7520 \mathrm{E}-01$ \\
\hline 130 & $4.1727 \mathrm{E} 05$ & $2.5810 \mathrm{E}-01$ \\
\hline 131 & $4.0494 \mathrm{E} 05$ & $2.4010 E-01$ \\
\hline 132 & $3.9298 \mathrm{E} 05$ & $2.2160 \mathrm{E}-01$ \\
\hline 133 & $3.8136 \mathrm{E} 05$ & $2.026 n F-n 1$ \\
\hline 134 & $3.7009 \mathrm{E} 05$ & $1.8320 \mathrm{E}-01$ \\
\hline 135 & $3.5916 \mathrm{E}$ 05 & $1.6350 \mathrm{E}-01$ \\
\hline 136 & 3.485 /E 05 & $1.4350 \mathrm{E}-01$ \\
\hline 137 & $3.3824 \mathrm{E} \quad 05$ & $1.2330 \mathrm{E}-0.1$ \\
\hline 138 & $3.2825 \mathrm{E} 05$ & $1.0340 \mathrm{E}-01$ \\
\hline 139 & $3.1854 \mathrm{E} \quad 05$ & $8.9650 \mathrm{E}-02$ \\
\hline $\begin{array}{l}139 \\
140\end{array}$ & $3.0913 \mathrm{E} 05$ & $7.8590 \mathrm{E}-02$ \\
\hline 141 & $3.0000 \mathrm{E} 05$ & $7.3370 \mathrm{E}-02$ \\
\hline
\end{tabular}


efficiencies. The neutron groups are equally spaced in lethargy between $20 \mathrm{MeV}$ and $300 \mathrm{keV}$.

\section{B. Calculational Procedure}

Neutrons were followed from production to detection as a function of space, angle, and time. Neutron histories were started uniformly per unit lethargy from $20 \mathrm{MeV}$ to the lowest energy with reported experimental data. The initial spatial coordinates of the neutrons were determined by selecting $x$ and $y$ uniformly over the effective cross-sectional area of the neutron beam and placing $z$ at the leading edge of the sample. Neutrons were started straight ahead in the $z$ direction.

Source neutrons in each energy group were given initial times determined by the time-of-flight of a neutron at the midpoint of each energy group to the leading edge of the sample. Relativistic velocities were used throughout the calculations. The initial times were smeared with a Gaussian approximation of the experimentally determined time spread as follows:

$$
\Delta t=(R 1-R 2) \times T
$$

where $R 1$ and $R 2$ are random numbers and $T=12 \mathrm{nsec}$.

The calculation model for the ORNL experiment is the same as that shown in Fig. 1 except for the fact that the detector was approximated as a point flux detector. This assumption was shown to have negligible effect on the results reported and simplified the calculations considerably.

Count rates were calculated as $\phi \times \varepsilon \times A$ where $\phi$ is the flux at the detector center determined by next flight estimation, $\varepsilon$ is the detector efficiency given in Table 1 , and $A$ is the detector cross-sectional area, $19.6 \mathrm{~cm}^{2}$. The count rates were converted to counts per MeV per incident source neutron by multiplying the count rate by the time bin width and by dividing by the corresponding energy group width in MeV. The fraction 
of incident neutrons in each energy group is equal (within statistics) since the group boundaries were equally spaced in lethargy and the starting energies were selected uniformly in lethargy.

The detector count rates were reported as functions of the incident neutron energy. The time bins for the calculation were determined from the energy group boundaries, E, as follows:

$$
T=\frac{D / c}{\sqrt{1-\frac{1}{\left(1-\frac{E^{1}}{2 c^{2}}\right)^{2}}}}
$$

where,

$T=f l i g h t$ time in sec from accelerator source to sample face for a neutron energy $E$ at the source,

$D=$ distance in $\mathrm{cm}$ from accelerator source to sample face, $E^{\prime}=1.91322 \times 10^{12} \times E$, where $E$ is the energy in MeV, $c=$ speed of lighl in $\mathrm{cm} / \mathrm{sec}$.

Although the neutron flight times scattering in the sample and traveling to the detector are illcluded in the calculations, they are generally small compared to the flight time of the neutrons from the source to the sample as determined by Eq. (2).

The calculated secondary energy spectra for the experiment included the empirically determined energy resolution of the detector given by $R$, the full-width at half-maximum value of the resolution function in percent:

$$
R=\sqrt{A+B / E}
$$

where $A$ was $250, B$ was 670 , and $E$ was an energy in MeV uniformly selected in the energy group of the detected particle. The spectra were obtained by. time-dependent calculations with time bins being determined by Eq. (2) where $E$ corresponded to the broad group energy boundaries used in unfolding the experimental pulse-height spectra. 
IV. Comparison of Experimental and Calculated Results

The figures which follow summarize the calculations performed for comparison with the experimental data. All calculations were made with the MORSE Monte Carlo code using the ENDF/B-IV iron cross-section set. The integral neutron count rate comparisons at 90 deg are given in Figs. 3,4 , and 5. In all figures the error bars represent one standard deviation of the mean value. Figures 6 through 12 give the secondary neutron energy spectra comparisons. In the multiple energy spectra figures, each set of comparisons is plotted at the mid-point of the appropriate incident neutron energy bin (i.e., the plot at $12 \mathrm{MeV}$ on the slanted energy scale corresponds to the spectrum of secondary neutrons arising from incident neutrons in the 11.0 to $13.0 \mathrm{MeV}$ energy range).

\section{Discussion}

The lack of a complete set of angular-dependent integral and spectral experimental data (i.e., results at other than $90 \mathrm{deg}$ ) make it difficult to draw conclusions about specific problems in the ENDF/B-IV iron data set specifically with regard to elastic scattering cross sections. It should be pointed out that as an integral detector, NE-213 is most responsive to neutrons with energies between $500 \mathrm{keV}$ and $2 \mathrm{MeV}$. Above and below this energy range the detector efficiencies drop off considerably (see Table I). The integral results therefore tend to be most sensitive to neutrons emerging at low energies from non-elastic scattering events. In addition to this factor, the choice of a 90-deg detector location also favors detection of non-elastically scattered neutrons. For all energies above $1 \mathrm{MeV}$ the angular distribution for elastic scattering is considerably forward peaked and in moving to high incident neutron energies 90-deg elastic scattering becomes decreasingly important compared to small angle scattering events. These two factors make the entire experiment predominantly a non-elastic scattering measurement test which is shown graphically in the spectral results given in Figs. 6 through 12 . 
What is clear from the integral results shown in Figs: 3,4 , and 5 is that there are significant disagreements between the experimental and calculated results. The largest discrepancies appear in the 10- to $12-\mathrm{MeV}$ incident neutron energy range where the calculations are low by about 30\%. In the 3- to 5-MeV range and above $14 \mathrm{MeV}$ smaller disagreements appear with the calculations being high by about 20\%. The results below $2.0 \mathrm{MeV}$ and more specifically below $1.0 \mathrm{MeV}$ (see Fig. 5) indicate some larger discrepancies. It appears, however, that these latter disagreements are the result of fine structure effects; in that the experimental data averaged over 100-keV intervals would be in good agreement with the calculated results. The angular-dependent elastic scattering cross-section data (1.e., Leyeridre coefficients) arc simply not evaluated to the resolution of the integral experiment data so the calculations only represent the average scattering behavior.

Turning to the secondary spectral results, it becomes somewhat easier to identify the cause of the observed discrepancies in the integral count rate results. From Figs. 6 through 8 it is clear that the elastic scattering portion of the secondary spectrum (curresponding to the highest energy peak in each curve) is calculated reasonably well for incident neutron energies up to about $4.0 \mathrm{MeV}$. As the inelastic levels in this energy range begin to contribute to the lower energy portion of the scattered neutron spectrum, large discrepancies begin to show up. In the 1.5 to $1.75 \mathrm{MeV}$ incident energy bin, scattering from the first inelastic level at $0.86 \mathrm{MeV}$ begins to appcar as a second peak in the curve at lower energies. The calculation of the secondary spectrum from such inelastic events appears to be overpredicted by as much as a factor of two; however. As each higher energy inelastic level is excited (at energies of $2.0,2.6$, and $3.0 \mathrm{MeV}$ ), a similar overprediction of the secondary neutron flux in the spectrum occurs (see Figs. 7 and 8 ). Moving $1 \mathrm{MeV}$ or more above the threshold of each level, however, seems to result in good agreement between calculated and experimental results. It appears to be the data in the region just above threshold (i.e., $300 \mathrm{keV}$ to $1 \mathrm{MeV}$ above threshold) that seems to be the cause of the discrepancies. These results are reflected in the integral curves which are very 


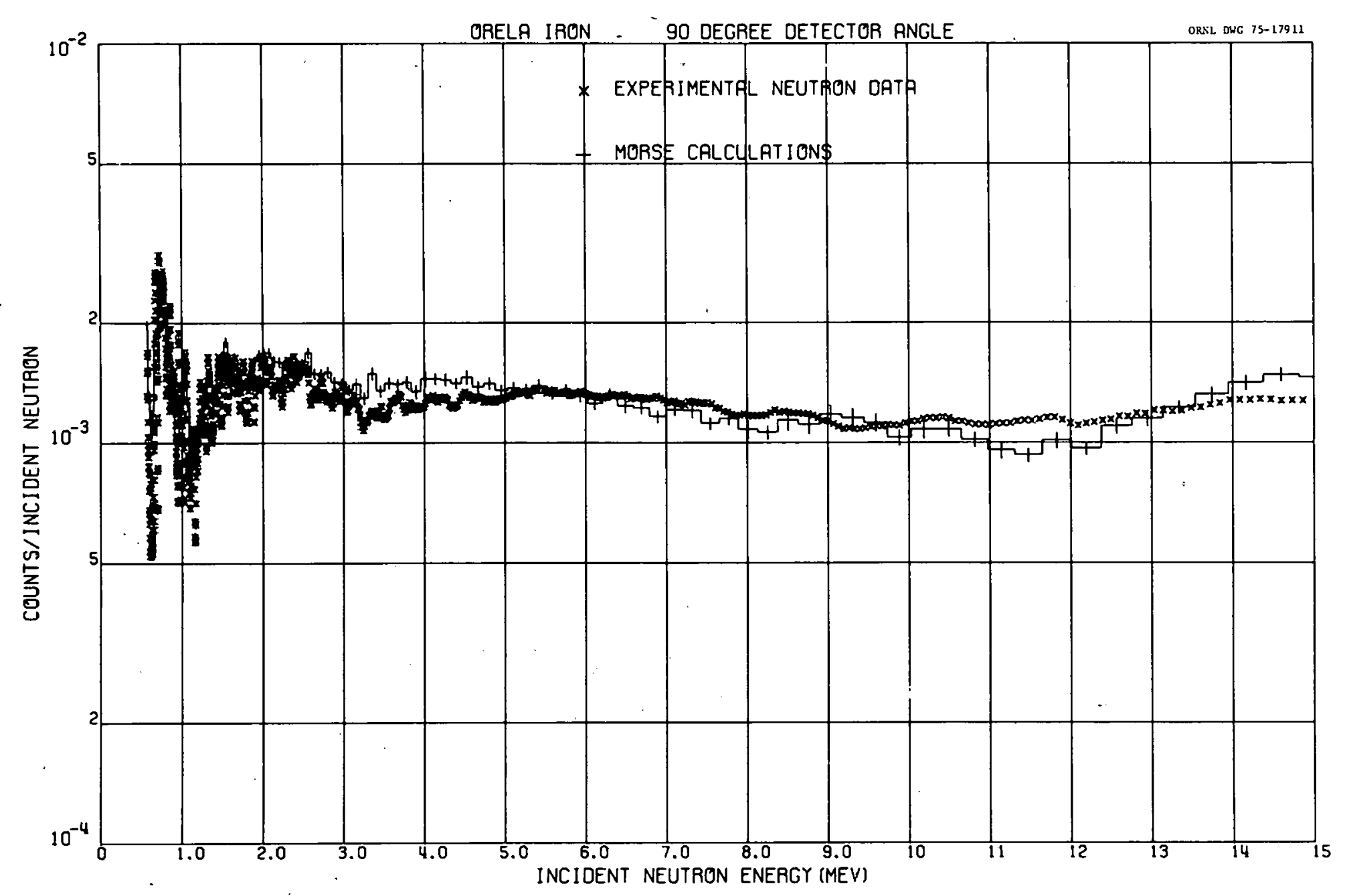

Fig. 3. Comparison of the Integral Count Rate Results for the ORNL Iron Integral Experiment. 


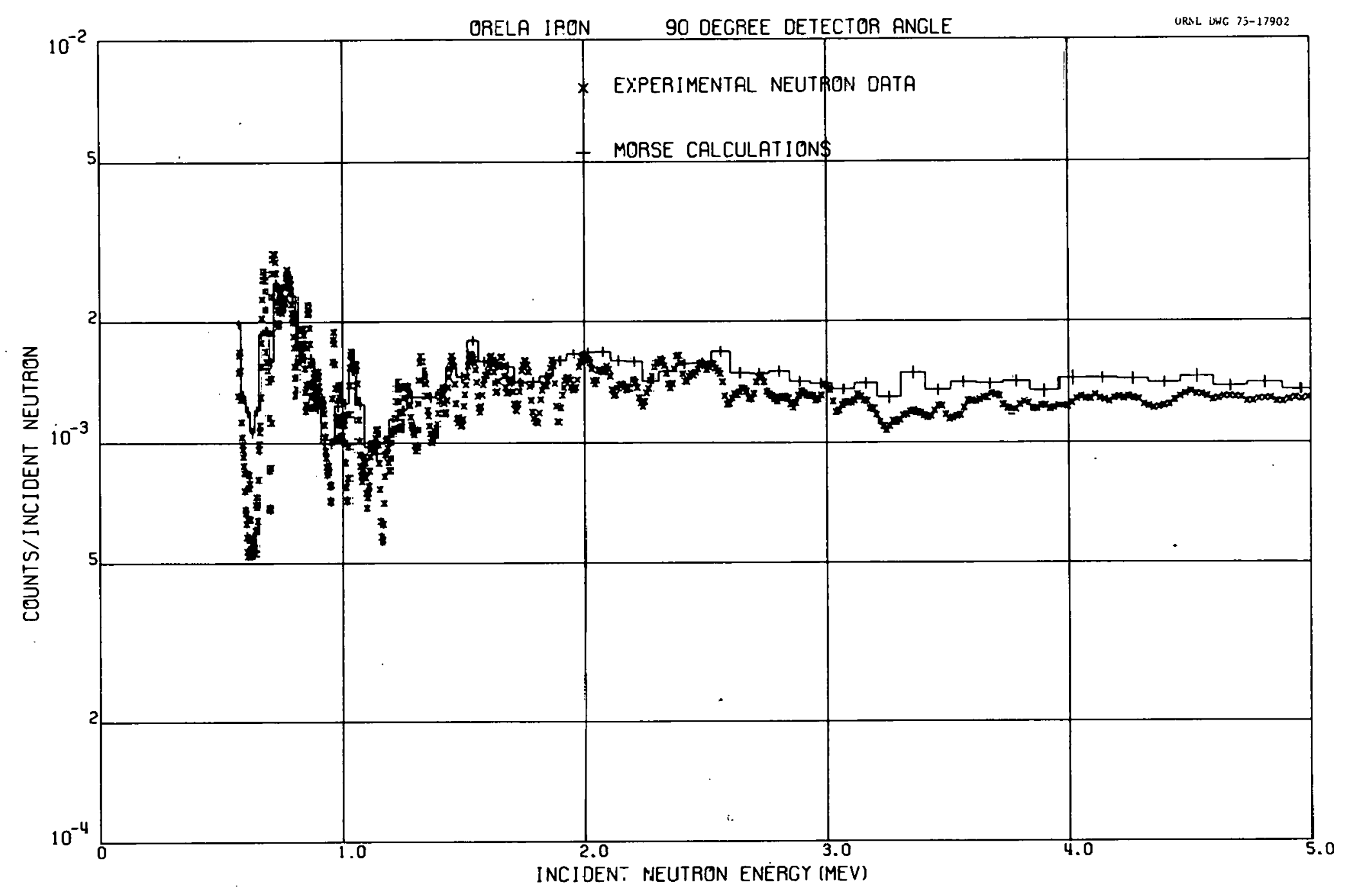

Fig. 4. Comparison of the Integral Count Rate Results for the ORNL Iron Integral Experiment. 


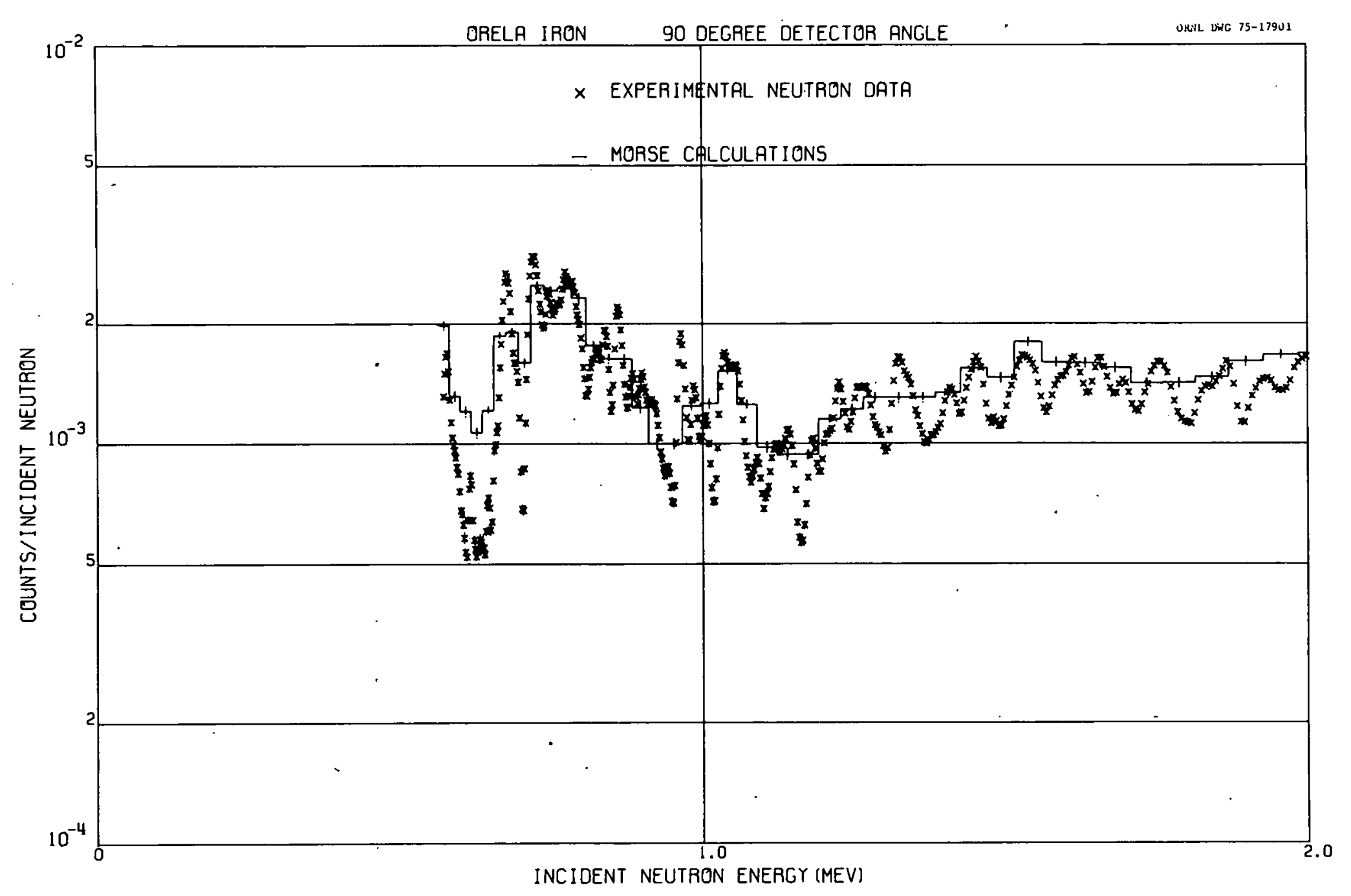

Fig. 5. Comparison of the Integral Count Rate Results for the ORNL Iron Integral Experiment. 
ORNL DWC 75-17892

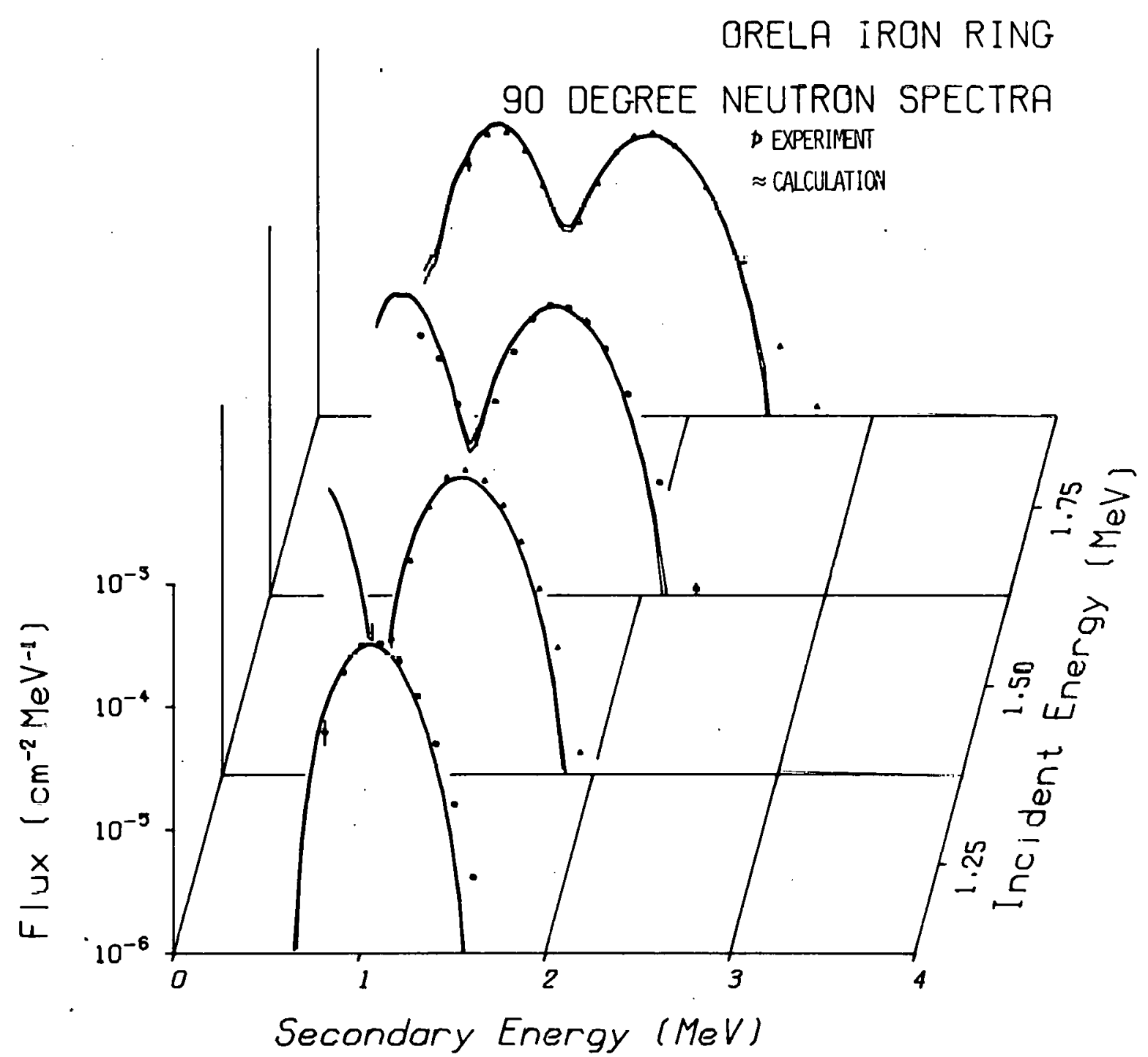

Fig. 6. Comparisuns of the Secondary Neutron Energy Spectra for the ORNL Iron Integral Experiment. 
OKNL DWG 75-17893

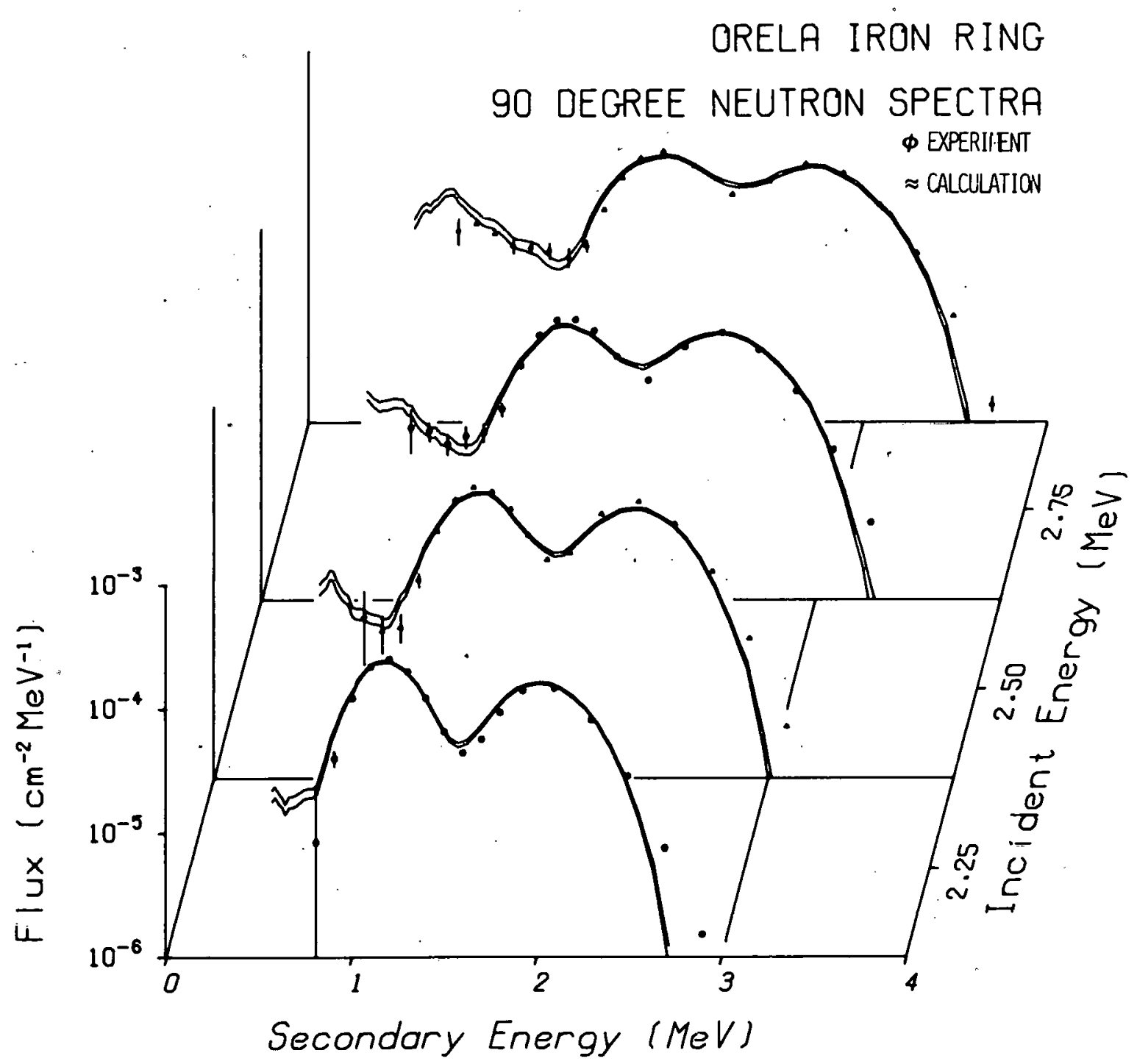

Fig. 7. Comparisons of the Secondary Neutron Energy Spectra for the ORNL Iron Integral Experiment. 
ORNL DWG $75-17894$

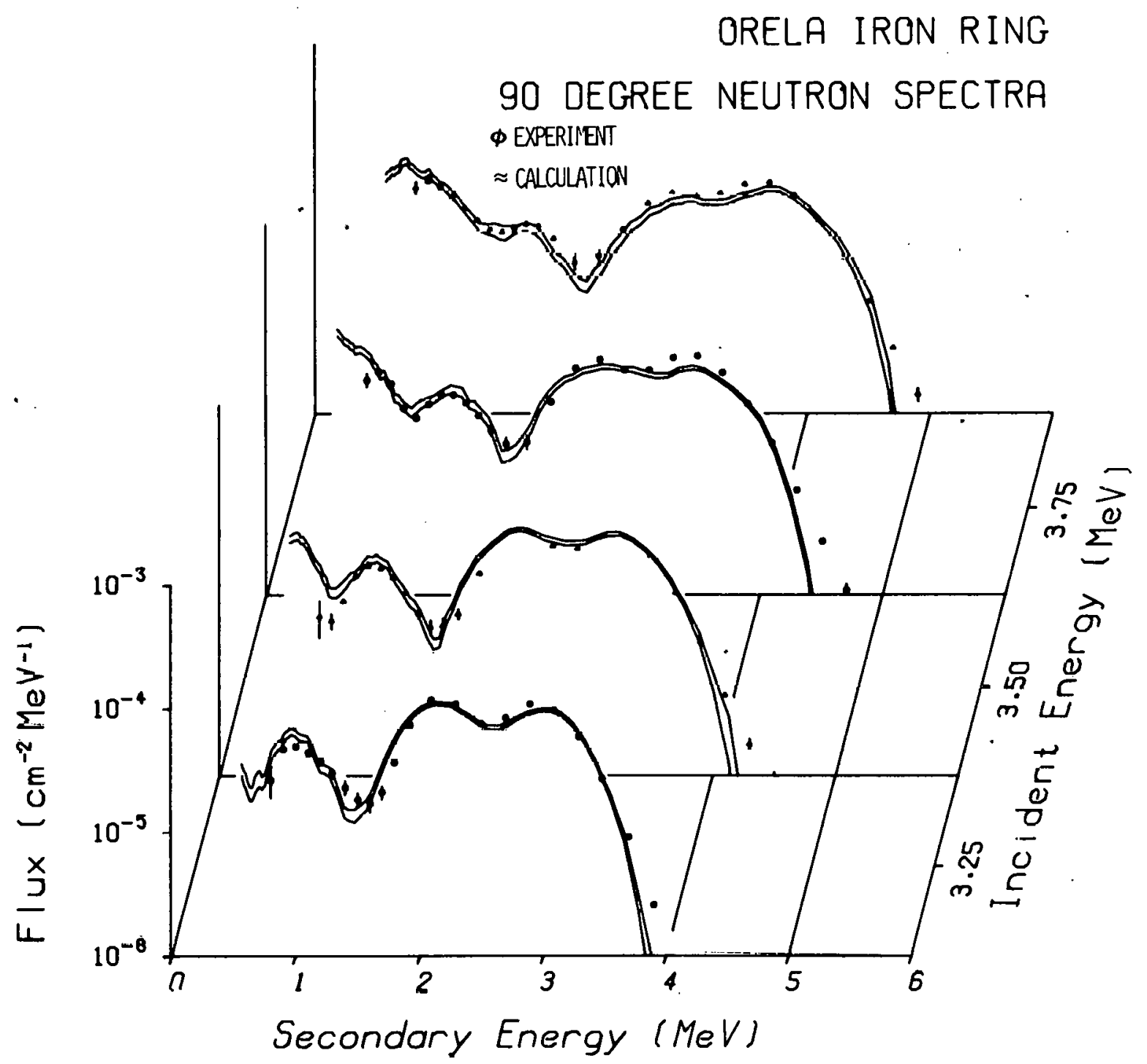

Fig. 8. Comparisuns of the Secondary Neutrun Energy Spectra for the ORNL Iron Integral Experiment. 
sensitive to such inelastic events as evidenced by the overpredictions at about $1.5 \mathrm{MeV}, 2.1 \mathrm{MeV}$ and above $2.6 \mathrm{MeV}$ in Fig. 4.

The trend in overpredicting the lowest energy end of the spectrum continues up through incident neutron energies of $7 \mathrm{MeV}$ (see Figs. 9 and 10). The evaluated data, on which the calculations are based, contain discrete level inelastic information up to incident neutron energies of about $4.5 \mathrm{MeV}$, at which point continuum inelastic data begins in tabulated form so as to retain some discrete level structure. Above $7 \mathrm{MeV}$ the evaluation changes over to a temperature model description of continuum inelastic. At the point of this changeover to the temperature model, the overpredictions just above threshold disappear and the calculated results agree with the experimental results up to about $10 \mathrm{MeV}$. This behavior would seem to indicate that problems exist in the cross section data for discrete inelastic scattering just above threshold. Less likely is the possibility that there is some anisotropy in inelastic events just above threshold (to check this latter effect data at other detector angles would be needed).

Above an incident neutron energy of about $10 \mathrm{MeVV}$ the tail of the secondary spectrum is uniformly undercalculated (see Figs. 11 and 12) except that at the highest energies near $14 \mathrm{MeV}$ the lower portion of the tail is overcalculated. These discrepancies, coupled with the NE-213 efficiency bias toward low energy neutrons, is responsible for the integral discrepancles seen in tigs. 3 through 5 . Above $10 \mathrm{MeV}$ several thresholds for scattering are reached, most important of which is the ${ }^{56} \mathrm{Fe}(n, 2 n)$ reaction threshold at about $11.2 \mathrm{MeV}$. Since the secondary spectra for continuum scattering reactions is more or less independent of initial energy, the low energy spectral discrepancies in the 1- to ?-MeV range are likely related to these partial cross sections. Although anisotropic effects cannot be ruled out completely, results from the Livermore pulsed sphere program 11,12 indicate similar secondary spectra behavior for angular integrated iron scattering results, supporting the above conclusion. The discrepancies in the 4- to 8-MeV region of the secondary spectra, on the other hand, are very likely the result of difficiencies in the continuum and discrete inelastic data. 
ORNL DWC 75-17895

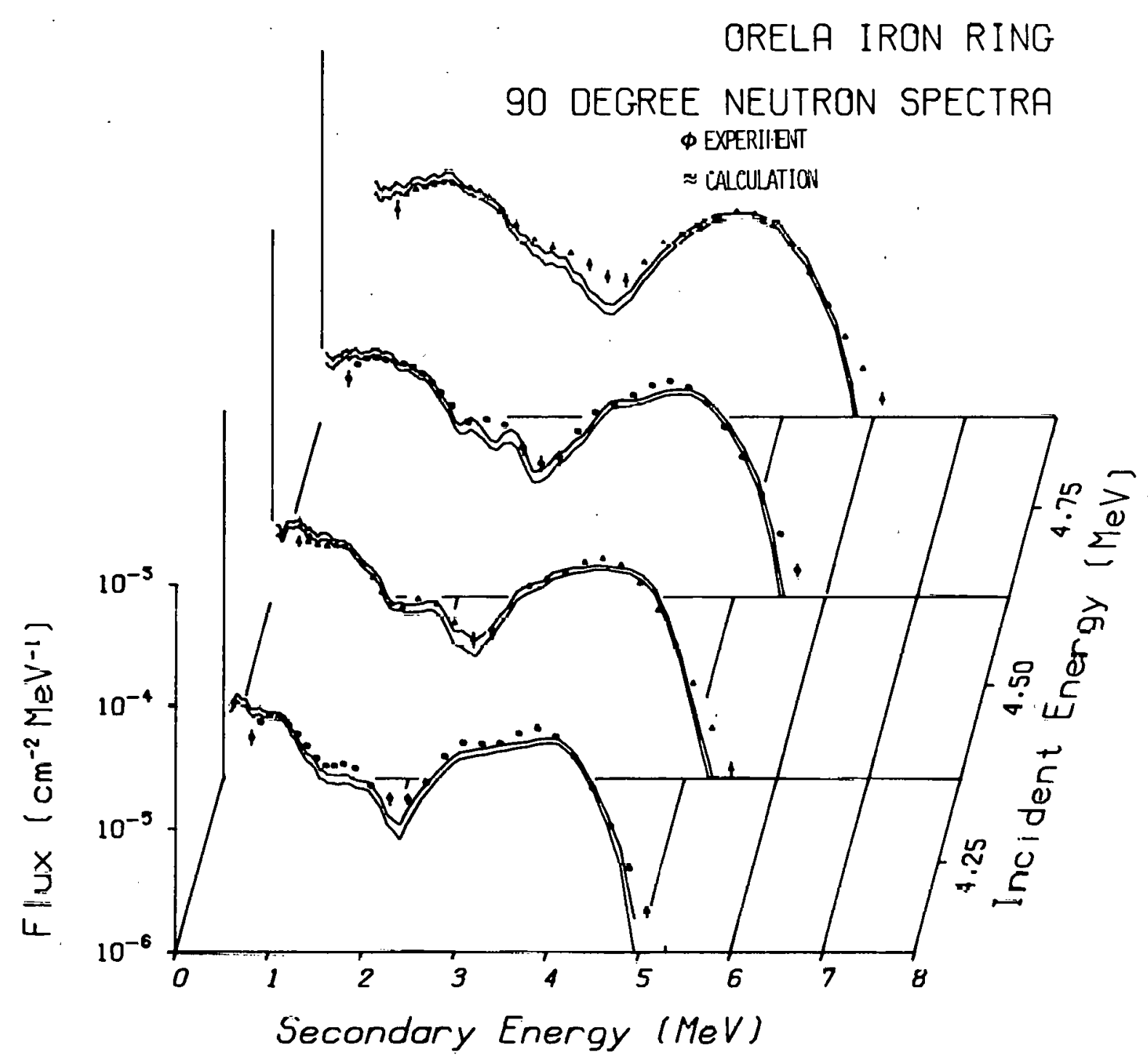

Fig. 9. Comparisons of the Secondary Neutron Energy Spectra for the ORNL Iron Integral Experiment. 


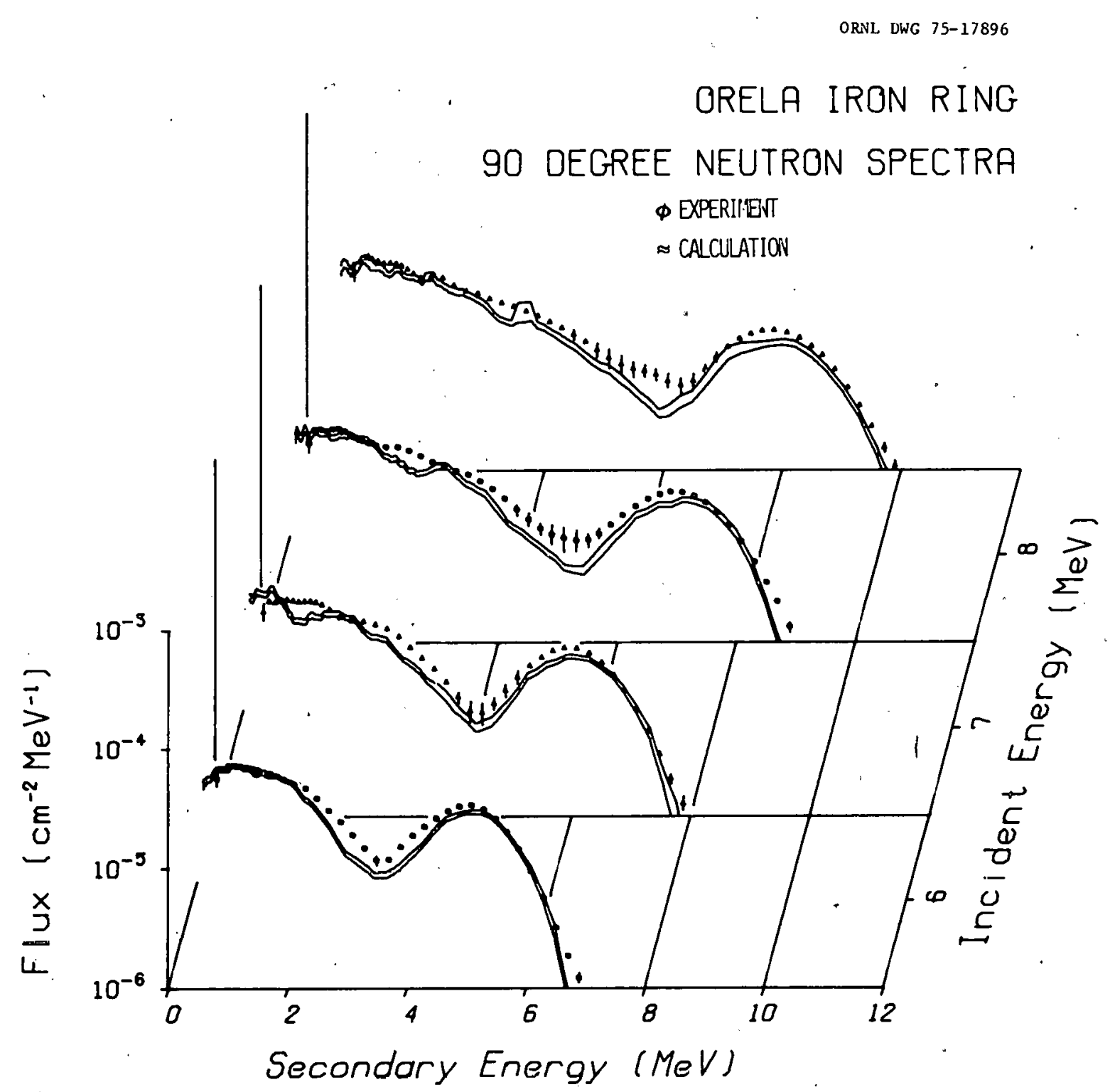

Fig. 10. Comparisons of the Secondary Neutron Energy Spectra for the ORNL Iron Integral Experiment. 


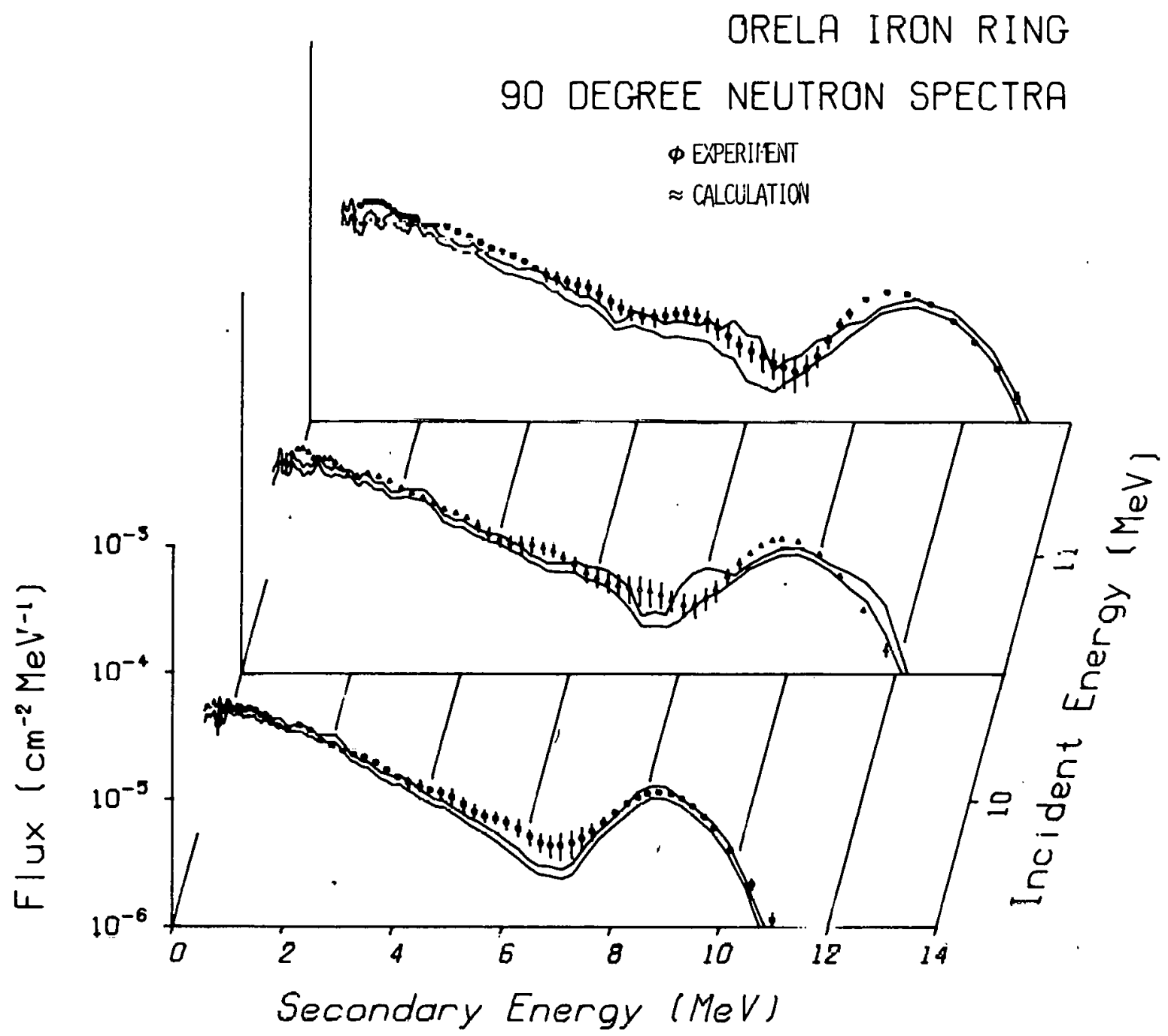

Fig. 11. Comparisons of the Secondary Neutron Energy Spectra for the URNL Iron Integral Experiment. 


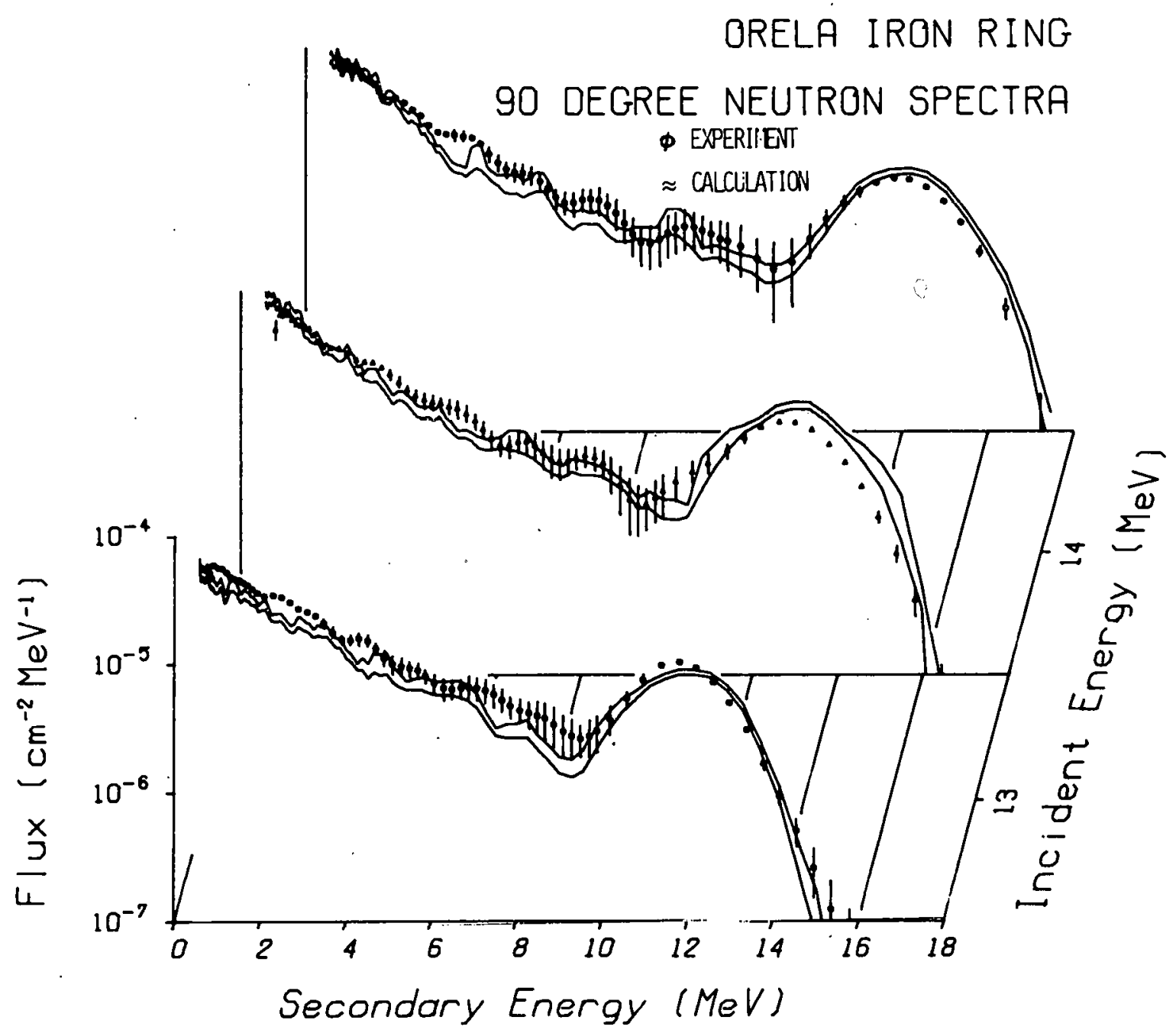

Fig. 12. Comparisons of the Secondary Neutron Energy Spectra for the ORNL Iron Integral Experiment. 
The valley in the secondary energy distribution between 8 to $10 \mathrm{MeV}$ in Fig. 12 showed discrepancies in past evaluations but it appears that the ENDF/B-IV data has remedied the problem. This region is very sensitive to the treatment of data for continuum and discrete inelastic scattering which lead to undercalculation of the spectrum by factors of two and three in previous analyses.9.10 As evidenced by the present results, the discrepancies caused by previous iron data files has more or less disappeared (although the statistical errors in the results are fairly large in this region). Recent calculations by Howerton ${ }^{12}$ for a similar integral experiment also confirm this conclusion. At lower incident neutron energies in the range from 6 to $10 \mathrm{MeV}$ the valley discrepancy does show up again and the problem here also is probably in the inelastic scattering cross section for discrete levels as handled by the combination of a tabulated data.file and a continuum temperature model treatment.

In all the curves above incident neutron energies of $5 \mathrm{MeV}$ there are large discrepancies in comparisons of secondary spectra near the elastic scattering peak. Although these results indicatc discrepancies that surely exist in the elastic data, elastic scattering to 90 deg is orders of magnitude lower than small angle scattering in iron at these energies. It appears difficult to get such a small angular-dependent cross section accurately measured and evaluated, but there are few applications where these events will be important. The high energy neutron albedo on an iron first wall in a CTR device might be one of these, however.

\section{Conclusions}

Several significant deficiencies in the ENDF/B-IV iron data files still exists as evidenced by the analysis of the ORNL experimental results. In the 1- to 4-MeV incident neutron energy range the cross sections for inelastic scattering to the first three levels in ${ }^{56} \mathrm{Fe}$ appear to be too large by from $30-100 \%$ just above threshold. At energies above 
$6 \mathrm{MeV}$ the continuum and tabulated discrete level inelastic data appear to be alternately too high or too low. From 6 to $12 \mathrm{MeV}$ the cross sections for both discrete inelastic and continuum inelastic data are too low and from 13 to $15 \mathrm{MeV}$ it appears that the continuum inelastic data are high and the cross sections for some inelastic levels are still low. Discrepancies appear in the elastic scattering data above incident neutron energies of about $5 \mathrm{MeV}$. Not too much significance can be placed in these disagreements, however, since the bulk of the scattering is highly forward peaked at these energies. The conclusions drawn about the nonelastic scattering data above $13 \mathrm{MeV}$ are consistent with results reported for iron from the Livermore pulsed sphere integral experiment program. 


\section{References}

1. G. L. Morgan, "Measurement of Secondary Neutrons and Gamma Rays Produced by Neutron Interaction with Nitrogen and Oxygen Over the Incident Energy Range 1 to $20 \mathrm{MeV}, "$ Oak Ridge National Laboratory report ORNL-TM-5023 (1975).

2. G. L. Morgan, T. A. Love, and F. G. Perey, "An Experimental System for Providing Data to Test Evaluated Secondary Neutron and GammaRay Production Cross Sections Over the Incident Neutron Energy Range from 1 to $20 \mathrm{MeV}, "$ Nucl. Instr. \& Meth., 128, 125 (1975).

3. S. N. Cramer and E. M. Ublow, "Analyses of Neutron Scattering and Gamma-Ray Production Integral Experiments on Carbon for Neutron Energies from 1 to $15 \mathrm{MeV}$," Oak Ridge National Laboratory report ORNL-TM-4494 (1974); see also, Nucl. Sci. Eng., 58, 33 (1975).

4. S. N. Cramer and E. M. Oblow, "Analysis of Neutron Scattering and Gamma-Ray Production Integral Experiments on Nitrogen for Neutron Energies from 1 to $15 \mathrm{MeV}$," Oak Ridge National Laboratory report ORNL-TM-5220 (1976).

5. S. N. Cramer and E. M. Oblow, "Analys is of a Neutron Scattering and Gamma-Ray Production Integral Experiment on 0xygen for Neutron Energies from 1 to $15 \mathrm{MeV}$," Oak Ridge National Laboratory report ORNL-TM-5535 (1976).

6. M. B. Emmett, "The MUKSE Monte Carlo Radiation Transport Conde System," Oak Ridge National Láboratury report ORNL 4972 (1875).

7. R. W. Roussin, "The Defense Nuclear Agency Working Cross Section Library - Description and Contents; "Nak Ridge National Laboratory (Radiation Shielding Information Center) report ORNL-RSIC-34 (19\% $)$.

8. N. M. Greene et al., "AMPX - A Modular Code System to Generate Coupled Multigroup Neutron-Gamma Cross Sections from ENDF/B," Dak Ridge National Laboratory report ORNL-TM-3706 (1976).

9. L. F. Hansen et al., "Measuremients and Calculations of the Neutron Spectra from Iron Bombarded with 14-MeV Neutrons," Nucl. Sci. Eng., 51, $278(1973)$.

10. S. N. Cramer, R. W. Roussin, and E. M. Oblow, "Monte Carlo Calculations and Sensitivity Studies of the Time-Dependent Neutron Spectra Measured in the LLL Pulsed Sphere Program," Oak Ridge National Laboratory report ORNL-TM-4072 (1973). 
11. C. Wong et al., "Livermore Pulsed Sphere Program: Program Summary Through July 1971," UCRL-51144 Rev. I, Lawrence Livermore Laboratory (1972).

12. R. J. Howerton, "Testing of ENDF/B-IV-P Evaluations with SDT-10 Benchmark Pulsed Spheres," UCRL-75693, Lawrence Livermore Laboratory (1974). 
THIS PAGE

\section{WAS INTENTIONALLY LEFT BLANK}


ORNL/TM-5548

\section{Internal Distribution}

1. L. S. Abbott

2. R. G. Alsmiller, Jr.

3. D. E. Bartine

4. C. E. Clifford

5-9. S. N. Cramer

10. J. K. Dickens

11. C. Y. Fu

12. H. Goldstein (consultant)

13. W. E. Kinney

14. D. C. Larson

15. T. A. Love

16. R. E. Maerker

17. F. C. Maiens chein

18. G. L. Morgan

19. F. R. Mynatt

20-24. E. M. Oblow

25. R. W. Peelle

26. F. G. Perey
27. R. W. Rouss in

28. M. L. Tobias

29. C. R. Weisbin

30. A. Zucker

31. P. Greebler (consultant)

32. W. W. Havens, Jr. (consultant)

33. A. F. Henry (consultant)

34. R. E. Uhrig (consultant)

35-36. Central Research Library

37. ORNL Y-12. Technical Library Document Reference Section

38. Laboratory Records Department

39. Laboratory Records ORNL RC

40. ORNL Patent Office

41-42. Radiation Shielding Information Center

\section{External Distribution}

43. USERDA Oak Ridge Operations, Research \& Technical Support Division, P. 0. Box E, Oak Ridge, TN. 37830: Director

44-70. Technical Information Center

71. Research and Technical Support Division

72-144. Given special NPD DNA distribution 